\title{
Gene expression profiles in testis of pigs with extreme high and low levels of androstenone
}

\author{
Maren Moe*1,2, Theo Meuwissen²,3, Sigbjørn Lien 2,3, Christian Bendixen ${ }^{4}$, \\ Xuefei Wang, ${ }^{4}$ Lene Nagstrup Conley, Ingunn Berget ${ }^{3,5}$, Håvard Tajet ${ }^{1,2}$ and \\ Eli Grindflek ${ }^{1,3}$
}

Address: ${ }^{1}$ The Norwegian Pig Breeders Association (NORSVIN), Hamar, Norway., ${ }^{2}$ Department of Animal and Aquacultural Sciences, Norwegian University of Life Sciences, Ås, Norway., ${ }^{3}$ Centre for Integrative Genetics (CIGENE), Norwegian University of Life Sciences, Ås, Norway., ${ }^{4}$ Faculty of Agricultural Sciences, University of Aarhus, Tjele, Denmark. and ${ }^{5}$ MATFORSK, Osloveien 1, Ås, Norway.

Email: Maren Moe* - maren.moe@umb.no; Theo Meuwissen - theo.meuwissen@umb.no; Sigbjørn Lien - sigbjorn.lien@umb.no; Christian Bendixen - Christian.Bendixen@agrsci.dk; Xuefei Wang - Wang.Xuefei@agrsci.dk; Lene Nagstrup Conley - LeneN.Conley@agrsci.dk; Ingunn Berget - ingunn.berget@umb.no; Håvard Tajet - haavard.tajet@norsvin.no; Eli Grindflek - eli.grindflek@umb.no

* Corresponding author

Published: 7 November 2007

BMC Genomics 2007, 8:405 doi:10.1 186/147|-2164-8-405

This article is available from: http://www.biomedcentral.com//47I-2/64/8/405

(c) 2007 Moe et al; licensee BioMed Central Ltd.

This is an Open Access article distributed under the terms of the Creative Commons Attribution License (http://creativecommons.org/licenses/by/2.0), which permits unrestricted use, distribution, and reproduction in any medium, provided the original work is properly cited.
Received: 3 July 2007

Accepted: 7 November 2007

\begin{abstract}
Background: Boar taint is a major obstacle when using uncastrated male pigs for swine production. One of the main compounds causing this taint is androstenone, a pheromone produced in porcine testis. Here we use microarrays to study the expression of thousands of genes simultaneously in testis of high and low androstenone boars. The study allows identification of genes and pathways associated with elevated androstenone levels, which is essential for recognising potential molecular markers for breeding purposes.
\end{abstract}

Results: Testicular tissue was collected from 60 boars, 30 with extreme high and 30 with extreme low levels of androstenone, from each of the two breeds Duroc and Norwegian Landrace. The samples were hybridised to porcine arrays containing 26,877 cDNA clones, detecting 563 and 160 genes that were differentially expressed ( $P$ $<0.01$ ) in Duroc and Norwegian Landrace, respectively. Of these significantly up- and down-regulated clones, 72 were found to be common for the two breeds, suggesting the possibility of both general and breed specific mechanisms in regulation of, or response to androstenone levels in boars. Ten genes were chosen for verification of expression patterns by quantitative real competitive PCR and real-time PCR. As expected, our results point towards steroid hormone metabolism and biosynthesis as important biological processes for the androstenone levels, but other potential pathways were identified as well. Among these were oxidoreductase activity, ferric iron binding, iron ion binding and electron transport activities. Genes belonging to the cytochrome P450 and hydroxysteroid dehydrogenase families were highly up-regulated, in addition to several genes encoding different families of conjugation enzymes. Furthermore, a number of genes encoding transcription factors were found both up- and down-regulated. The high number of clones belonging to ferric iron and iron ion binding suggests an importance of these genes, and the association between these pathways and androstenone levels is not previously described.

Conclusion: This study contributes to the understanding of the complex genetic system controlling and responding to androstenone levels in pig testis. The identification of new pathways and genes involved in the biosynthesis and metabolism of androstenone is an important first step towards finding molecular markers to reduce boar taint. 


\section{Background}

The production of uncastrated male pigs is profitable to the swine production, because it leads to improved feed efficiency and greater lean yield of the carcass [1]. However, production of entire males is a challenge due to boar taint, an unpleasant odour and flavour often present in the meat of un-castrated male pigs [2]. Castration is undesirable both for ethical as well as for economical reasons and thus alternative methods are needed to prevent tainted meat. Boar taint is primarily caused by high levels of the two components androstenone and/or skatole in the pig carcasses $[3,4]$. Moderate to high heritabilities have been shown for both androstenone and skatole levels in fat [5-7]. For example, a recent study of Duroc and Norwegian Landrace showed heritabilities ranging from 0.5-0.6 for androstenone and 0.23-0.56 for skatole [8].

Androstenone ( $5 \alpha$-androst-16-en-3-one) is a 16 -androstene steroid produced from pregnenolone in the steroid hormone pathway in boar testis near sexual maturity. It is released into the blood and transported to salivary glands [9], where it regulates reproductive functions in female pigs [10]. Due to its lipophilic properties, it is also easily stored in the adipose tissue [11], causing boar taint when the fat is heated. Another steroid produced from pregnenolone in the same pathway is testosterone. Testosterone stimulates growth and fertility and the challenge is to reduce the level of androstenone without affecting the level of testosterone. Genes specifically affecting the production of androstenone in the testis are therefore of interest, as well as genes involved in degradation and elimination of this steroid.

Several candidate genes have been suggested to affect levels of androstenone. The biosynthesis of 16-androstenes from pregnenolone is catalysed by the andien- $\beta$ synthase enzyme system [12], which consists of cytochrome P450C17 (CYP17) and cytochrome b5 (CYB5) [13]. Although CYP17 has been proposed as a very potent candidate gene affecting levels of androstenone, studies so far have not found significant effects of SNPs within the CYP17 gene and androstenone levels [14,15]. Similarly, it has not been possible to find a significant correlation between levels of CYP17 and levels of 16-androstene steroids in fat [14]. CYB5 has been found positively correlated to the production of androstenone [14]. In addition, a SNP in the 5 ' un-translated region of porcine CYB5 is found to be associated with decreased fat androstenone levels [16].

Another potent class of candidate genes is the sulphotransferase (SULT) enzymes whose main function is to transfer a sulfo group to a range of molecules including for example steroid hormones [17]. The SULTs have been proposed to regulate the amount of unconjugated $5 \alpha$ androstenone available for accumulation in fat [18], and high proportions of sulphoconjugated to unconjugated 16 -androstene steroids are observed in porcine plasma and Leydig cells $[18,19]$.

The levels of androstenone vary between breeds, with e.g. higher androstenone levels in Duroc and Hampshire compared to Landrace and Yorkshire [20]. It is therefore of interest to investigate gene expression patterns in individuals with high or low levels of androstenone in different breeds. In this study boars with extreme levels of androstenone were selected from the two commercial breeding populations in Norway, Duroc and Norwegian Landrace, for gene expression analysis in testis using microarray technology. The objective of the study was to identify differentially expressed genes that could point towards pathways associated with extreme levels of androstenone in pigs. To our knowledge, this is the first microarray experiment performed in this context.

\section{Results}

Porcine cDNA microarrays containing 26,877 clones were used to examine the transcript profile of Duroc (D) and Norwegian Landrace (NL) pigs with high (H) and low (L) levels of androstenone. A total of 1533 NL boars and 1027 $\mathrm{D}$ boars were analysed and average androstenone levels were $1.17 \pm 1.15 \mu \mathrm{g} / \mathrm{g}$ and $3.22 \pm 2.68 \mu \mathrm{g} / \mathrm{g}$ for NL and D, respectively. 30 high and 30 low androstenone boars were selected from each breed and average values were $5.91 \pm$ $2.41 \mu \mathrm{g} / \mathrm{g}$ for NL high androstenone (NLH), $0.15 \pm 0.04$ $\mu \mathrm{g} / \mathrm{g}$ for NL low androstenone (NLL), $10.27 \pm 2.68 \mu \mathrm{g} / \mathrm{g}$ for D high androstenone (DH) and $0.42 \pm 0.13 \mu \mathrm{g} / \mathrm{g}$ for D low androstenone (DL). Testicle derived samples were hybridised using a balanced block design and significantly affected genes were identified using linear models (Limma). Box plots (See Additional file 1: Boxplot of the arrays) show that the deviation of the raw log ratios from 0 was successfully normalised. The statistical test detected 563 and 160 clones as differentially expressed in D and NL, respectively $(\mathrm{p}<0.01)$ (See Additional file 2 : Microarray results analysed using Limma, Duroc and Additional file 3: Microarray results analysed using Limma, Norwegian Landrace). The top 100 genes are presented for $\mathrm{D}$ (Table 1) and NL (Table 2). Venn diagrams were created to explore any overlap between breeds and 72 genes were found in common for D and NL (See Additional file 4: Genes common for Duroc and Norwegian Landrace at $\mathrm{p}<$ $0.01)$. Another more robust, but less powerful non-parametric test for statistical analysis, namely Fisher's Sign Test (FST) was performed as well. (See Additional file 5: Microarray results analysed using Fisher's sign test, Duroc and additional file 6: Microarray results analysed using Fisher's sign test, Norwegian Landrace).

The cDNA clones found to be differentially expressed were used to search for statistically overrepresented gene ontol- 
Table I: Top 100 genes identified in Duroc

\begin{tabular}{|c|c|c|c|c|}
\hline ID & Name & gene_id & M & adj.P.Val \\
\hline 211570 & Similar to hypothetical protein (LOC475I55) & $\underline{X M ~ 532385.1}$ & 0.746 & $4.28 \mathrm{e}-12$ \\
\hline 103463 & Cytochrome P450 I7AI (CYPI7AI) & NM 214428.1 & 1.227 & $6.05 \mathrm{e}-12$ \\
\hline 218005 & & & 1.100 & $8.28 \mathrm{e}-12$ \\
\hline 217877 & Ferritin, light polypeptide (FTL) & NM 000146.3 & 1.033 & $1.27 \mathrm{e}-1 \mid$ \\
\hline 209883 & & & 0.550 & $1.29 \mathrm{e}-11$ \\
\hline 213434 & Eukaryotic translation elongation factor I alpha I (EEFIAI) & NM 001402.4 & 1.084 & $1.29 \mathrm{e}-1 \mathrm{I}$ \\
\hline 203529 & Cystatin F (leukocystatin) (CST7) & NM 003650.2 & 0.726 & $1.57 \mathrm{e}-1 \mid$ \\
\hline 102025 & Cytochrome b-5 (CYB5) & NM 001001770.1 & 0.529 & $1.57 \mathrm{e}-\mathrm{I}$ \\
\hline 210231 & Ferritin, light polypeptide (FTL) & NM 000146.3 & 1.032 & I.57e- $\mid$ I \\
\hline 215500 & Ferritin, light polypeptide (FTL) & NM 000146.3 & 0.986 & $5.24 \mathrm{e}-11$ \\
\hline 210851 & Ferritin, light polypeptide (FTL) & NM 000146.3 & 1.006 & $6.23 \mathrm{e}-11$ \\
\hline 216813 & Kallikrein 6 (neurosin, zyme) (KLK6), transcript variant C & NM 001012965.1 & 0.892 & $6.45 \mathrm{e}-11$ \\
\hline 211448 & Golgi phosphoprotein 3-like (GOLPH3L) & NM 018178.3 & 0.927 & $1.55 \mathrm{e}-10$ \\
\hline 103177 & Cytochrome b-5 (CYB5) & NM 001001770.1 & 0.768 & $9.43 e-10$ \\
\hline 216525 & Chromosome 22 open reading frame 16 (C22orfl6) & NM 213720.1 & 0.639 & $1.52 \mathrm{e}-09$ \\
\hline 214052 & Carbonyl reductase/NADP-retinol dehydrogenase (DHRS4) & NM 214019.1 & 0.889 & $1.64 \mathrm{e}-09$ \\
\hline 218092 & Procollagen C-endopeptidase enhancer (PCOLCE) & NM 002593.2 & 0.606 & $1.69 \mathrm{e}-09$ \\
\hline 100650 & Brain expressed, $X$-linked I (BEXI) & NM 018476.2 & 0.537 & $1.98 \mathrm{e}-09$ \\
\hline 216417 & DNA helicase HEL308 (HEL308) & NM 133636.1 & 0.757 & 2.11e-09 \\
\hline 217089 & Chromosome 20 open reading frame 22 (C20orf22) & NM 015600.2 & 0.812 & $2.19 \mathrm{e}-09$ \\
\hline 211821 & Phosphatidylserine receptor (PTDSR) & NM 015167.1 & 0.891 & $2.61 \mathrm{e}-09$ \\
\hline 213358 & Microtubule-associated protein I light chain 3 alpha (MAPILC3A) & NM 032514.2 & 0.811 & $3.78 \mathrm{e}-09$ \\
\hline 206784 & Ferritin heavy-chain (FTHI) & NM 213975.1 & 0.478 & $4.72 \mathrm{e}-09$ \\
\hline 216513 & Prostate androgen-regulated transcript I (PARTI) & NM 016590.2 & 0.693 & $4.72 \mathrm{e}-09$ \\
\hline 101322 & Ferredoxin (FDXI) & NM 214065.1 & 0.498 & $8.99 e-09$ \\
\hline 215969 & $\mathrm{~N}$-acetylglucosamine-I-phosphotransferase, gamma subunit (GNPTG) & NM 032520.3 & 0.517 & $1.67 e-08$ \\
\hline 211898 & POU domain, class 3 , transcription factor 2 (POU3F2) & NM 005604.2 & 0.643 & $3.56 \mathrm{e}-08$ \\
\hline 209731 & Ferritin heavy-chain (FTHI) & NM 213975.I & 0.595 & $3.56 \mathrm{e}-08$ \\
\hline 214602 & Acetyl-Coenzyme A carboxylase alpha (ACACA), transcript variant 2 & NM 198839.1 & 0.473 & $6.06 \mathrm{e}-08$ \\
\hline 100718 & Adenylate kinase $3(\mathrm{AK} 3)$ & NM 016282.2 & 0.445 & $6.06 \mathrm{e}-08$ \\
\hline 213748 & Hypothetical protein LOC284106 (LOC284106) & XM 375449.1 & 0.304 & $7.54 \mathrm{e}-08$ \\
\hline 216045 & Phosphodiesterase 4D, cAMP-specific (PDE4D) & NM 006203.3 & 0.670 & $7.54 \mathrm{e}-08$ \\
\hline 218317 & Ferritin heavy-chain (FTHI) & NM 213975.1 & 0.332 & $8.53 e-08$ \\
\hline 211683 & Ferritin heavy-chain (FTHI) & NM 213975.1 & 0.537 & $9.79 e-08$ \\
\hline 202380 & Protein phosphatase I, regulatory subunit 2 pseudogene 3 (PPPIR2P3) & NR 002168.1 & 0.497 & $1.16 \mathrm{e}-07$ \\
\hline 103450 & 3-hydroxy-3-methylglutaryl-Coenzyme A synthase I (soluble) (HMGCSI) & NM 002130.4 & 0.387 & $1.16 \mathrm{e}-07$ \\
\hline 210738 & Ferritin heavy-chain $(\mathrm{FTHI})$ & NM 213975.1 & 0.538 & $1.65 e-07$ \\
\hline 217101 & Leucine zipper protein I (LUZPI) & NM 033631.2 & 0.741 & $1.84 \mathrm{e}-07$ \\
\hline 209872 & Aldo-keto reductase family I, member C4 (AKRIC4) & NM 001818.2 & 0.634 & $3.65 e-07$ \\
\hline 101435 & Muscle-specific intermediate filament desmin (LOC396725) & NM_001001535.1 & 0.559 & $4.57 e-07$ \\
\hline 207680 & Myelin expression factor 2 (MYEF2) & NM 016132.2 & 0.344 & $8.37 e-07$ \\
\hline 103619 & Glucan (I,4-alpha-), branching enzyme I (GBEI) & NM 000158.1 & 0.417 & $1.44 \mathrm{e}-06$ \\
\hline 205158 & Glutathione S-transferase (MGSTI) & NM 214300.1 & 0.447 & $1.59 \mathrm{e}-06$ \\
\hline 103416 & Peroxiredoxin 3 (PRDX3), nuclear gene encoding mitochondrial protein & NM 014098.2 & 0.436 & $1.68 \mathrm{e}-06$ \\
\hline 210951 & Ferritin heavy-chain (FTHI) & NM 213975.1 & 0.491 & $1.94 \mathrm{e}-06$ \\
\hline $2|454|$ & Homeo box (H6 family) I (HMXI) & NM 018942.1 & 0.334 & $2.17 \mathrm{e}-06$ \\
\hline 217401 & Phosphate regulating gene (Phex) & NM 011077.1 & 0.592 & $2.82 \mathrm{e}-06$ \\
\hline 201622 & Hypothetical protein LOC2850I6 (LOC2850I6) & NM 001002919.1 & 0.591 & $3.08 \mathrm{e}-06$ \\
\hline 217377 & & & 0.607 & $3.40 \mathrm{e}-06$ \\
\hline 217497 & Similar to coronin, actin binding protein, 2B (LOC5I7030) & $\underline{X M 595194.1}$ & 0.507 & $3.43 e-06$ \\
\hline 101570 & Sorting nexin 3 (SNX3), transcript variant I & NM 003795.3 & 0.230 & $3.61 \mathrm{e}-06$ \\
\hline 216333 & Brcal associated protein I (Bapl) & NM 027088.1 & 0.297 & $3.74 \mathrm{e}-06$ \\
\hline 101369 & Translocase of inner mitochondrial membrane 13 homolog (TIMMI3) & NM 012458.2 & 0.333 & $3.98 \mathrm{e}-06$ \\
\hline 216897 & Zinc finger protein 229 (ZNF229) & NM 014518.1 & 0.696 & $3.98 \mathrm{e}-06$ \\
\hline 201672 & & & $0.4 I I$ & $4.07 e-06$ \\
\hline 100874 & Ubiquitin-conjugating enzyme E2R 2 (UBE2R2) & NM 017811.3 & -0.453 & $4.31 \mathrm{e}-06$ \\
\hline 217389 & SMAD, mothers against DPP homolog I (Drosophila) (SMADI) & NM 001003688.1 & 0.623 & $5.08 \mathrm{e}-06$ \\
\hline 103364 & Sulfotransferase family, cytosolic, 2A, member I (SULT2AI) & NM 003167.2 & 0.325 & $5.08 \mathrm{e}-06$ \\
\hline 214446 & & & 0.484 & $5.08 \mathrm{e}-06$ \\
\hline
\end{tabular}


Table I: Top 100 genes identified in Duroc (Continued)

\begin{tabular}{|c|c|c|c|c|}
\hline 103263 & Retinol dehydrogenase 12 (all-trans and 9-cis) (RDHI2) & NM 152443.1 & 0.336 & $6.64 \mathrm{e}-06$ \\
\hline 220907 & 3-hydroxy-3-methylglutaryl-Coenzyme A synthase I (soluble) (HMGCSI) & NM 002130.4 & 0.363 & $7.29 \mathrm{e}-06$ \\
\hline 217413 & Suppressor of cytokine signaling 5 (SOCS5), transcript variant I & NM 014011.4 & 0.609 & $8.04 \mathrm{e}-06$ \\
\hline 209887 & & & 0.416 & $8.52 \mathrm{e}-06$ \\
\hline 211211 & KIAA0999 protein (KIAA0999) & NM 025164.3 & 0.284 & $9.46 \mathrm{e}-06$ \\
\hline 104110 & Cytochrome P450 5I (CYP5I) & NM 214432.1 & 0.365 & $9.98 \mathrm{e}-06$ \\
\hline 204992 & & & 0.381 & I. $12 \mathrm{e}-05$ \\
\hline 100545 & Isopentenyl-diphosphate delta isomerase (IDII) & NM 004508.2 & 0.365 & $1.38 \mathrm{e}-05$ \\
\hline 100618 & Myelin basic protein (MBP) & NM 001001546.1 & 0.272 & $1.38 \mathrm{e}-05$ \\
\hline 104176 & Aminolevulinate, delta-, synthase I (ALASI), transcript variant I & NM 000688.4 & 0.407 & $1.42 \mathrm{e}-05$ \\
\hline 211043 & Testis expressed sequence $26 \mathrm{I}$ (TEX26I) & NM 144582.2 & 0.390 & $1.42 \mathrm{e}-05$ \\
\hline 209191 & Chromosome 20 open reading frame 50 (C20orf50) & $\underline{X M \quad 046437.7}$ & 0.416 & $1.42 \mathrm{e}-05$ \\
\hline $22|3| 1$ & & & 0.331 & $1.42 \mathrm{e}-05$ \\
\hline 201823 & Cytochrome b-5 (CYB5) & NM 001001770.1 & 0.439 & $1.66 \mathrm{e}-05$ \\
\hline 209002 & Malic enzyme 2, NAD(+)-dependent, mitochondrial (ME2) & NM 002396.3 & -0.232 & $1.66 \mathrm{e}-05$ \\
\hline 212725 & Immunoglobulin superfamily, member 8 (IGSF8) & NM 052868.1 & 0.181 & $1.89 \mathrm{e}-05$ \\
\hline 203290 & Hypothetical protein MGC332I4 (MGC332I4) & NM 153354.2 & -0.268 & 2. $10 \mathrm{e}-05$ \\
\hline 103537 & Regulatory factor X, 2 (influences HLA class II expression) (RFX2) & NM 000635.2 & 0.495 & $2.16 \mathrm{e}-05$ \\
\hline 211919 & & & 0.430 & 2. $16 \mathrm{e}-05$ \\
\hline 220629 & Chromosome 6 open reading frame 89 (C6orf89) & gi|4727|470|ref| & -0.451 & $2.16 \mathrm{e}-05$ \\
\hline 200365 & HDCMAI8P protein (HDCMAI8P) & NM 016648.1 & -0.342 & $2.23 e-05$ \\
\hline 207244 & Superoxide dismutase I, soluble (SODI) & NM 000454.4 & 0.267 & $2.26 \mathrm{e}-05$ \\
\hline 102085 & Steroid membrane binding protein (PGRMCI) & NM 213911.1 & 0.265 & $2.33 e-05$ \\
\hline 103751 & Glutathione peroxidase 4 (GPX4) & NM 214407.1 & 0.447 & $2.34 \mathrm{e}-05$ \\
\hline 204615 & Solute carrier organic anion transporter family, member IB3 (SLCOIB3) & NM 019844.1 & 0.297 & $2.65 e-05$ \\
\hline 102131 & Integral membrane protein $2 \mathrm{~B}$ (ITM2B) & NM 021999.2 & 0.327 & $2.95 \mathrm{e}-05$ \\
\hline 100094 & Poly(A) binding protein, cytoplasmic I (PABPCI) & NM 002568.3 & 0.375 & 3.07e-05 \\
\hline 201085 & & & 0.344 & $3.16 \mathrm{e}-05$ \\
\hline 219913 & Similar to Probable RNA-dependent helicase p68 (LOC505I5I) & XM 581395.1 & 0.418 & $3.21 \mathrm{e}-05$ \\
\hline 215566 & Protein phosphatase 4 (formerly X), catalytic subunit (PPP4C) & NM 002720.1 & 0.330 & $3.37 e-05$ \\
\hline 216418 & Similar to omega protein (LOC91353) & NM 001013618.1 & 0.240 & $3.54 \mathrm{e}-05$ \\
\hline 215949 & Hypothetical LOC400I 20 (LOC400I20) & NM 20345I.I & 0.604 & $3.56 \mathrm{e}-05$ \\
\hline 103431 & C-myc binding protein (MYCBP) & NM 012333.3 & 0.236 & $3.98 \mathrm{e}-05$ \\
\hline 101450 & & & 0.306 & $4.34 \mathrm{e}-05$ \\
\hline 209773 & Similar to protein RAKc (LOC439947) & $\underline{X M} 495795.1$ & 0.462 & $4.46 \mathrm{e}-05$ \\
\hline 105008 & Cytochrome P450 I9A2 (CYPI9A2) & NM 214430.1 & 0.418 & $5.57 e-05$ \\
\hline 103550 & Phosphoenolpyruvate carboxykinase I (soluble) (PCKI) & NM 002591.2 & -0.299 & $5.57 e-05$ \\
\hline 206124 & Solute carrier family 24, member 5 (SLC24A5) & NM 205850.1 & -0.211 & $5.96 \mathrm{e}-05$ \\
\hline 212000 & Upstream of NRAS (UNR), transcript variant 2 & NM 007158.4 & 0.239 & $5.96 \mathrm{e}-05$ \\
\hline 214660 & HSPC038 protein (LOC5II23) & NM 016096.2 & 0.232 & $6.01 \mathrm{e}-05$ \\
\hline
\end{tabular}

Gene profiling was done using 30 arrays and analysed using linear models. Fold change (M-values) and statistical significance (FDR-adjusted p-values) is shown. The clone names refer to hits to human, mouse or pig genes. Some genes are represented by several different clones on the array and may therefore show up more than once in the table, while some have no hits to the abovementioned species.

ogy (GO) terms compared with the GOs represented by all the genes on the array. The most significant terms analysed for molecular function in D were ferric iron binding, iron ion binding, oxidoreductase activity and steroid binding (Figure 1). For NL we also found terms related to functions like electron transport and steroid dehydrogenase activity (Figure 1). Furthermore, the genes were classified according to their biological processes (Figure 2) and cellular components (See Additional file 7: Gene ontology (GO) results for the cellular component ontology, Duroc and Additional file 8: Gene ontology (GO) results for the cellular component ontology, Norwegian Landrace). The biological processes most significant in both breeds were steroid biosynthesis and steroid metabolism.
Both real competitive PCR (rCPCR) and real-time PCR were used to validate expression profiles for ten of the interesting differentially expressed genes from the microarray experiment. Real-time PCR was used to confirm the expression of CYP17, CYB5, ferritin light polypeptide (FTL) and translation elongation factor 1 alpha 1 (EEF1A1) in the D samples. The NL pigs were not included in this study. The expression levels of all genes were normalized to $\beta$-actin (ACTB) and $18 \mathrm{~S}$ rRNA. Three of the four genes, FTL, CYB5 and CYP17, were confirmed by this method, while for EEF1A1 no significant difference was found (Table 3). rcPCR was used to analyse gene expression profiles of sphingomyelin phosphodiesterase 1 (SMPD1), steroidogenic acute regulatory protein (StAR), sulfotransferase family $2 \mathrm{~A}$, dehydroepiandroster- 
Table 2: Top 100 genes identified in Norwegian Landrace

\begin{tabular}{|c|c|c|c|c|}
\hline ID & Name & gene_id & M & adj.P.Val \\
\hline 214052 & Carbonyl reductase/NADP-retinol dehydrogenase (DHRS4) & NM 214019.1 & 1.106 & $1.94 \mathrm{e}-08$ \\
\hline 213358 & Microtubule-associated protein I light chain 3 alpha (MAPILC3A) & NM $0325 \mid 4.2$ & 0.805 & $2.41 \mathrm{e}-08$ \\
\hline 210231 & Ferritin, light polypeptide (FTL) & NM 000146.3 & 0.884 & $2.49 \mathrm{e}-08$ \\
\hline 103463 & Cytochrome P450 I7AI (CYPI7AI) & NM 214428.1 & 1.278 & $3.06 \mathrm{e}-08$ \\
\hline 209574 & KIAAI423 (KIAAI423) & XM 376550.2 & 0.466 & $3.06 \mathrm{e}-08$ \\
\hline 215500 & Ferritin, light polypeptide (FTL) & NM 000146.3 & 0.820 & $3.27 e-08$ \\
\hline 210851 & Ferritin, light polypeptide (FTL) & NM 000146.3 & 0.910 & $4.39 e-08$ \\
\hline 211570 & Similar to hypothetical protein (LOC475I55) & XM 532385.1 & 0.488 & $9.99 e-08$ \\
\hline 217877 & Ferritin, light polypeptide (FTL) & NM 000146.3 & 0.838 & $1.76 \mathrm{e}-07$ \\
\hline 218005 & & & 0.902 & $1.82 \mathrm{e}-07$ \\
\hline 220047 & Cell division cycle associated 7 (CDCA7), transcript variant I & NM 031942.3 & -0.524 & $2.21 \mathrm{e}-07$ \\
\hline 203529 & Cystatin F (leukocystatin) (CST7) & NM 003650.2 & 0.727 & $3.30 \mathrm{e}-07$ \\
\hline 211448 & Golgi phosphoprotein 3-like (GOLPH3L) & NM 018178.3 & 0.778 & $4.07 e-07$ \\
\hline 213434 & Eukaryotic translation elongation factor I alpha I (EEFIAI) & NM 001402.4 & 0.884 & $4.76 \mathrm{e}-07$ \\
\hline 213869 & PRAI domain family, member 2 (PRAF2) & NM 007213.1 & 0.258 & $1.79 \mathrm{e}-06$ \\
\hline 105119 & Steroidogenic acute regulatory protein (STAR) & NM 213755.2 & 0.378 & $1.79 \mathrm{e}-06$ \\
\hline 100252 & Ras homolog gene family, member Q (Rhoq) & NM 053522.1 & 0.330 & $4.40 \mathrm{e}-06$ \\
\hline 209883 & & & 0.442 & $7.35 \mathrm{e}-06$ \\
\hline 211898 & POU domain, class 3 , transcription factor 2 (POU3F2) & NM 005604.2 & 0.541 & $7.81 \mathrm{e}-06$ \\
\hline 102025 & Cytochrome b-5 (CYB5) & NM 001001770.1 & 0.397 & $8.88 \mathrm{e}-06$ \\
\hline 209731 & Ferritin heavy-chain (FTHI) & NM 213975.I & 0.421 & $2.15 e-05$ \\
\hline 201622 & Hypothetical protein LOC2850I6 (LOC2850I6) & NM 001002919.1 & 0.602 & $2.60 \mathrm{e}-05$ \\
\hline 101322 & Ferredoxin (FDXI) & NM 214065.I & 0.420 & $2.69 \mathrm{e}-05$ \\
\hline 206784 & Ferritin heavy-chain (FTHI) & NM 213975.1 & 0.345 & $4.90 \mathrm{e}-05$ \\
\hline 209887 & & & 0.378 & $5.19 \mathrm{e}-05$ \\
\hline 215969 & $\mathrm{~N}$-acetylglucosamine- I-phosphotransferase, gamma subunit (GNPTG) & NM 032520.3 & 0.362 & $5.50 \mathrm{e}-05$ \\
\hline 211014 & Elastin microfibril interfacer 2 (EMILIN2) & NM 032048.2 & 0.235 & $5.50 \mathrm{e}-05$ \\
\hline 211919 & & & 0.393 & $5.50 \mathrm{e}-05$ \\
\hline 210951 & Ferritin heavy-chain (FTHI) & NM 213975.1 & 0.401 & $6.77 e-05$ \\
\hline 105008 & Cytochrome P450 I9A2 (CYPI9A2) & NM 214430.1 & 0.338 & $8.16 \mathrm{e}-05$ \\
\hline 210738 & Ferritin heavy-chain (FTHI) & NM 213975.I & 0.424 & $8.16 e-05$ \\
\hline 201823 & Cytochrome b-5 (CYB5) & NM 001001770.1 & 0.454 & $8.16 \mathrm{e}-05$ \\
\hline 100826 & Chromosome 15 open reading frame 24 (CI5orf24) & NM 020154.2 & -0.230 & $8.39 \mathrm{e}-05$ \\
\hline 101872 & Anthrax toxin receptor I (ANTXRI), transcript variant I & NM 032208.1 & 0.339 & $8.39 \mathrm{e}-05$ \\
\hline 211040 & Cytochrome P450 IIAI (CYPIIAI) & NM 214427.I & 0.479 & $9.63 e-05$ \\
\hline 103622 & Chaperonin containing TCPI, subunit 4 (delta) (CCT4) & NM 006430.2 & 0.222 & 0.00010 \\
\hline 211683 & Ferritin heavy-chain (FTHI) & NM 213975.1 & 0.390 & 0.00010 \\
\hline 209678 & Parvin, gamma (PARVG) & NM 022141.4 & 0.354 & 0.00012 \\
\hline 211043 & Testis expressed sequence $26 \mathrm{I}$ (TEX26I) & NM 144582.2 & 0.321 & 0.00014 \\
\hline 100650 & Brain expressed, $\mathrm{X}$-linked I (BEXI) & NM_018476.2 & 0.410 & 0.00017 \\
\hline 102207 & Similar to RUN and FYVE domain-containing 2 (LOC44I022) & XM 496700.1 & 0.322 & 0.00019 \\
\hline 202502 & A disintegrin and metalloproteinase domain 5 (ADAM5) & $\overline{N R \quad 001448.1}$ & 0.265 & 0.00019 \\
\hline 221253 & Adaptor-related protein complex I, mu 2 subunit (APIM2) & NM 005498.3 & 0.277 & 0.00019 \\
\hline 210077 & Cytochrome P450 2C49 (CYP2C49) & NM 214420.1 & 0.211 & 0.00020 \\
\hline 201085 & & & 0.288 & 0.00021 \\
\hline 211785 & Zinc finger, DHHC domain containing I4 (ZDHHCl4) & NM 153746.I & 0.346 & 0.00023 \\
\hline 104944 & GTP cyclohydrolase I (dopa-responsive dystonia) $(\mathrm{GCHI})$ & NM 000161.1 & -0.593 & 0.00024 \\
\hline 201672 & & & 0.293 & 0.00026 \\
\hline 102125 & Hypothetical protein HSPCI38 (HSPCI 38) & NM 016401.2 & 0.209 & 0.00026 \\
\hline 211821 & Phosphatidylserine receptor (PTDSR) & NM 015167.1 & 0.726 & 0.00033 \\
\hline 204992 & & & 0.415 & 0.00036 \\
\hline 202380 & Protein phosphatase I, regulatory subunit 2 pseudogene 3 (PPPIR2P3) & NR 002168.1 & 0.422 & 0.00037 \\
\hline 213748 & Hypothetical protein LOC284I06 (LOC284I06) & $\underline{X M \quad 375449.1}$ & 0.221 & 0.00037 \\
\hline 103177 & Cytochrome b-5 (CYB5) & NM 001001770.1 & 0.566 & 0.00037 \\
\hline 103075 & Emopamil binding protein (sterol isomerase) (EBP) & NM 006579.1 & 0.227 & 0.00038 \\
\hline 210827 & Membrane-associated protein 17 (MAPI7) & NM 001001769.1 & 0.269 & 0.00039 \\
\hline 213497 & NADH dehydrogenase (ubiquinone) I, I, 6kDa (NDUFCI) & NM 002494.2 & 0.271 & 0.00039 \\
\hline 104615 & Superoxide dismutase I, soluble (SODI) & NM 000454.4 & 0.268 & 0.00040 \\
\hline 103619 & Glucan (I,4-alpha-), branching enzyme I (GBEI) & NM 000158.1 & 0.291 & 0.00046 \\
\hline
\end{tabular}


Table 2: Top 100 genes identified in Norwegian Landrace (Continued)

\begin{tabular}{|c|c|c|c|c|}
\hline 214976 & Cyclin M2 (CNNM2), transcript variant I & NM 017649.3 & 0.181 & 0.00049 \\
\hline 216693 & Calcium/calmodulin-dependent protein kinase II beta (CAMK2B) & NM 17208I.I & -0.404 & 0.00052 \\
\hline 101799 & Sarcolemma associated protein (SLMAP) & NM $007 \mid 59.2$ & 0.298 & 0.00052 \\
\hline 100935 & ADP-ribosylation-like factor 6 interacting protein 6 (ARL6IP6) & NM 152522.2 & 0.246 & 0.00053 \\
\hline 203697 & Hypothetical protein MGC40579 (MGC40579) & NM 152776.I & 0.394 & 0.00055 \\
\hline 101031 & RIKEN cDNA B230380D07 gene (B230380D07Rik) & NM 172772.1 & 0.354 & 0.00055 \\
\hline 209872 & Aldo-keto reductase family I, member C4 (AKRIC4) & NM 001818.2 & 0.634 & 0.00057 \\
\hline 102689 & Sulfotransferase family, cytosolic, 2A (SULT2AI) & NM 003167.2 & 0.326 & 0.00060 \\
\hline 214972 & Similar to Bax inhibitor-I (BI-I) (LOC45I883) & XM 509049.1 & 0.269 & 0.00060 \\
\hline 209191 & Chromosome 20 open reading frame 50 (C20orf50) & XM 046437.7 & 0.342 & 0.00062 \\
\hline 101010 & NADH dehydrogenase (ubiquinone) flavoprotein I, $5 \mathrm{IkDa}$ (NDUFVI) & NM 007103.2 & 0.195 & 0.00069 \\
\hline 217625 & Leucine rich repeat neuronal I (LRRNI) & NM 020873.3 & 0.235 & 0.00070 \\
\hline 100267 & Transducer of ERBB2, I (TOBI) & NM 005749.2 & 0.252 & 0.00070 \\
\hline 204605 & Maltase-glucoamylase (alpha-glucosidase) (MGAM) & NM 004668.1 & -0.273 & 0.00070 \\
\hline 100575 & I7beta-estradiol dehydrogenase (HSDI7B4) & NM 214306.1 & 0.262 & 0.00070 \\
\hline 104294 & Sarcoglycan, epsilon (SGCE) & NM 003919.1 & 0.223 & 0.00075 \\
\hline 214602 & Acetyl-Coenzyme A carboxylase alpha (ACACA), transcript variant 2 & NM 198839.1 & 0.294 & 0.00085 \\
\hline 100781 & Protein kinase, AMP-activated, beta 2 non-catalytic subunit (PRKAB2) & NM 005399.3 & 0.267 & 0.00090 \\
\hline 204606 & & & -0.229 & 0.00091 \\
\hline 100545 & Isopentenyl-diphosphate delta isomerase (IDII) & NM 004508.2 & 0.266 & 0.00111 \\
\hline 210439 & FK506 binding protein IA, I2kDa (FKBPIA), transcript variant I2B & NM 000801.2 & 0.233 & 0.00112 \\
\hline 101524 & Alpha-I,3-galactosyltransferase (GGTAI) & NM 213810.1 & 0.274 & 0.00120 \\
\hline 103263 & Retinol dehydrogenase 12 (all-trans and 9-cis) (RDHI2) & NM 152443.1 & 0.297 & 0.00124 \\
\hline 201437 & Hypothetical protein MGC40489 (MGC40489) & XM 373742.3 & -0.239 & 0.00124 \\
\hline 219641 & Ras association (RalGDS/AF-6) domain family 4 (RASSF4) & NM 032023.3 & 0.294 & 0.00124 \\
\hline 218092 & Procollagen C-endopeptidase enhancer (PCOLCE) & NM 002593.2 & 0.330 & 0.00124 \\
\hline 214348 & Glycerol-3-phosphate dehydrogenase I-like (GPDIL) & NM 015141.2 & 0.205 & 0.00133 \\
\hline 210245 & Complement component I, $r$ subcomponent (CIR) & NM 001733.2 & 0.221 & 0.00136 \\
\hline 209875 & Scavenger receptor class B member I (SCARBI) & NM 213967.1 & 0.253 & 0.00145 \\
\hline 105364 & Tumor necrosis factor, alpha-induced protein 6 (TNFAIP6) & $\overline{N M 007 I 15.2}$ & 0.241 & 0.00147 \\
\hline 212682 & Sulfotransferase family, cytosolic, 2B, member I (SULT2BI) & NM 177973.1 & 0.206 & 0.00149 \\
\hline 102760 & & & 0.310 & 0.00152 \\
\hline 101913 & Heat shock 60kDa protein I (chaperonin) (HSPDI) & NM 002156.4 & 0.265 & 0.00154 \\
\hline 214601 & Serine/threonine kinase 19 (STK 19), transcript variant I & NM 004197.1 & 0.298 & 0.00160 \\
\hline 101632 & Nuclear receptor coactivator 2 (NCOA2) & NM 006540.1 & 0.287 & 0.00160 \\
\hline 210848 & Annexin A7 (ANXA7), transcript variant I & NM 001156.2 & 0.182 & 0.00160 \\
\hline 221285 & Serine (or cysteine) proteinase inhibitor, clade B member 3 (SERPINB3) & NM 006919.1 & 0.225 & 0.00160 \\
\hline 219203 & Peroxiredoxin 2 (PRDX2), nuclear gene encoding mitochondrial protein & NM 005809.4 & 0.325 & 0.00170 \\
\hline 216273 & & & 0.257 & 0.00185 \\
\hline 217065 & Endonuclease G-like I (ENDOGLI) & NM 005107.1 & -0.364 & 0.00185 \\
\hline 211482 & Ubiquitin-conjugating enzyme E2R 2 (UBE2R2) & NM 017811.3 & 0.229 & 0.00196 \\
\hline
\end{tabular}

Gene profiling was done using 30 arrays and analysed using linear models. Fold change (M-values) and statistical significance (FDR-adjusted p-values) is shown. The clone names refer to hits to human, mouse or pig genes. Some genes are represented by several different clones on the array and may therefore show up more than once in the table, while some have no hits to the abovementioned species.

one-preferring, member 1 (SULT2A1), 17-beta-hydroxysteroid dehydrogenase IV (HSD17B4), aldo-keto reductase family 1, member C4 (AKR1C4), and cytochrome P450, subfamily XIA, polypeptide 1 (CYP11A1). The expression levels of all genes were normalised using the housekeeping gene hypoxanthine guanine phosphoribosyltransferase 1 (HPRT). StAR, SULT2A1, HSD17B4, AKR1C4 and CYP11A1 were all differentially expressed in both $\mathrm{D}$ and NL $(p<0.01)$, while SMPD1 was not significantly differentially expressed in either of the two breeds (Table 4 and 5, respectively).

\section{Discussion}

The present study describes the transcriptional profiles of testicle from animals with extreme high and low levels of androstenone in D and NL boars. Some of these genes have already been shown to affect levels of androstenone, although most of them have not previously been described in this context. Both CYB5 and CYP17 were upregulated in both D high (DH) and NL high (NLH) animals and this was confirmed by real-time PCR. Overexpression of CYB5 cDNA clones in high androstenone animals agrees with results previously seen in protein expression studies $[13,14]$. Earlier studies on CYP17 have shown that polymorphisms in the coding region of the 


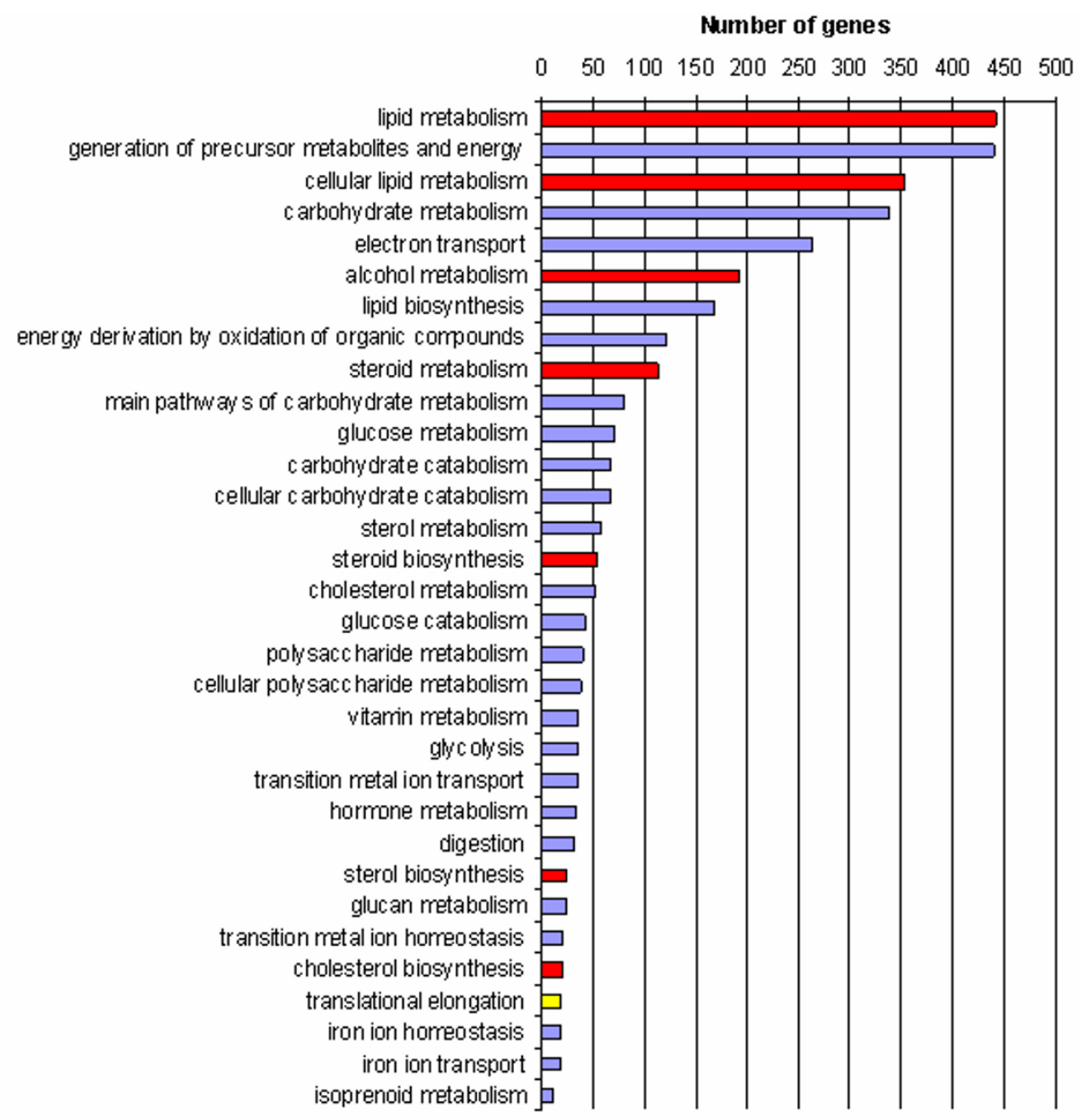

Figure I

Gene ontology (GO) results for the biological process ontology. The genes differentially expressed at $p<0.0 \mathrm{I}$ were analysed for over-represented GO terms in the biological process ontology. Some terms were common for Duroc and Norwegian Landrace (red) while some were only significant in Duroc (yellow) or Norwegian Landrace (blue). Number of genes is the number of genes that was found significantly differentially expressed $(p<0.01)$ for a term.

gene are not associated with androstenone levels [15], and that levels of the CYP17 protein are not correlated to levels of 16-androstene steroids in fat [14]. Notably, up-regulation of the gene expression of CYP17 in this study may be explained by its direct interaction with CYB5 in the andien- $\beta$ synthase enzyme system. Differential expression of both genes was confirmed by real-time PCR in the D boars of our study.

StAR is involved in the transport of cholesterol from the outer to the inner mitochondrial membrane, where CYP11A1 converts cholesterol to pregnenolone. This has been described as the rate-limiting step in steroid hormone synthesis, after which pregnenolone may exit the mitochondria and can be metabolised to steroid hormones [21]. The cholesterol side chain cleavage enzyme system contains ferredoxin (FDX1) which functions as an electron transport system, transferring electrons from NADPH-dependent ferredoxin reductase to CYP11A1 $[22,23]$. StAR was over-expressed in NLH, while FDX1 and CYP11A1 were over-expressed in both the DH and NLH groups. Our rcPCR results show that both StAR and CYP11A1 are highly up-regulated in the DH and NLH groups, even though the microarray study was not able to detect differences in the gene expression of StAR in DH. Based on results from the rCPCR study, StAR seems to particularly affect the androstenone level since this gene is up-regulated as much as five times in $\mathrm{DH}$ pigs and twelve times in NLH pigs. Emopamil-binding protein (EBP), sterol-C4-methyl oxidase-like isoform 1 (SC4MOL) and the cytochrome P450 enzyme lanosterol 14-alphademetylase (CYP51) are enzymes involved in the choles- 


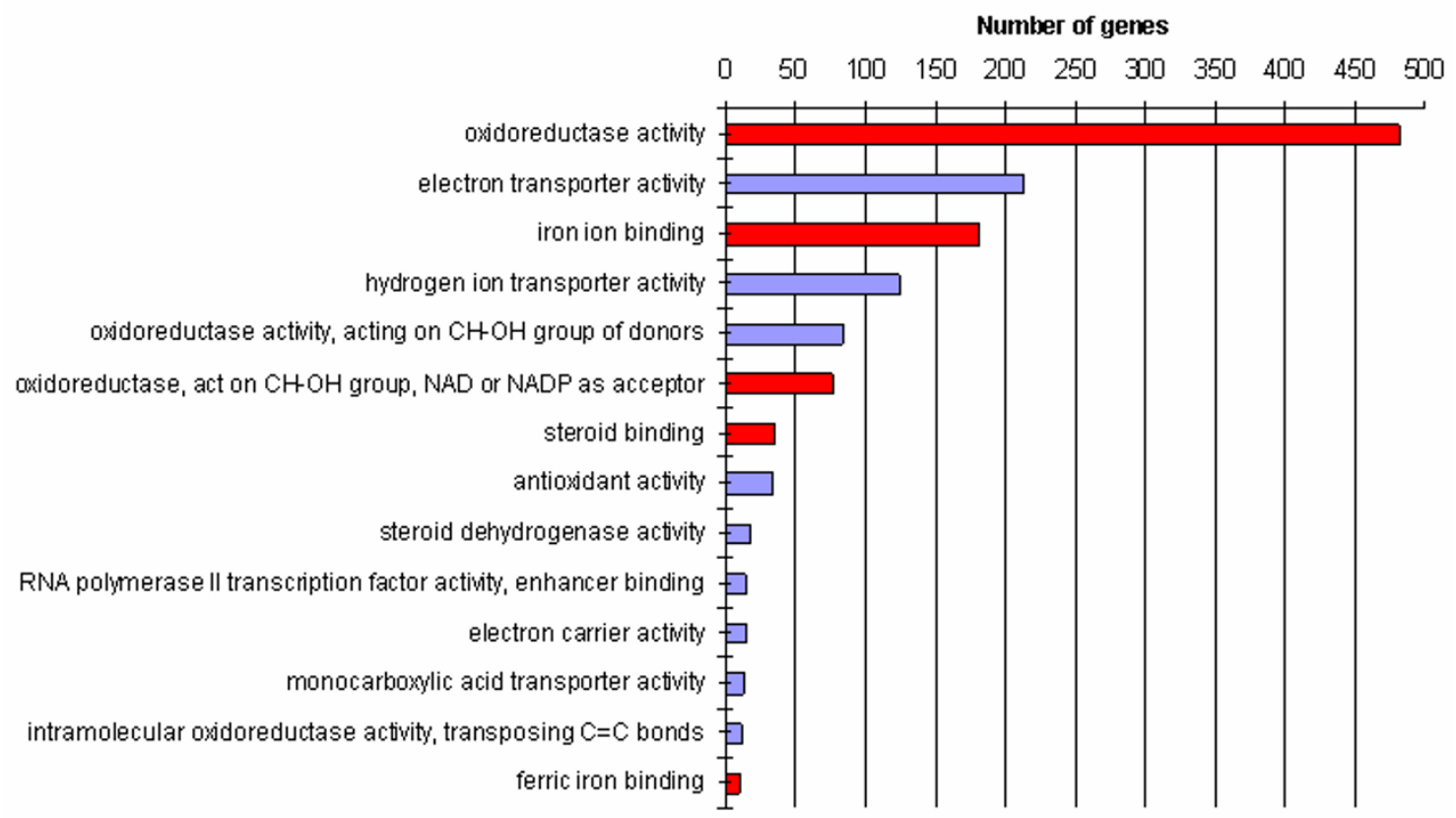

\section{Figure 2}

Gene ontology (GO) results for the molecular function ontology. The genes differentially expressed at $p<0.01$ were analysed for over-represented GO terms in the molecular function ontology. Some terms were common for Duroc and Norwegian Landrace (red) while some were only significant in Norwegian Landrace (blue). Number of genes is the number of genes that was found significantly differentially expressed $(p<0.01)$ for a term.

terol biosynthesis pathway [24-26]. EBP was up-regulated in NLH, while SC4MOL and CYP51 were up-regulated in the DH. Isopentenyl-diphosphate delta isomerase (IDI1) catalyses the inter-conversion of isopentenyl diphosphate (IPP) to dimethylallyl diphosphate (DMAPP), which is the substrate for the reaction that ultimately results in cholesterol, and this gene was up-regulated in both $\mathrm{DH}$ and NLH. The over-expression of all these genes may indicate that this early stage of steroid hormone biosynthesis is important for the production levels of androstenone. However, since cholesterol ultimately metabolises into both androstenone and testosterone, it might be impossi-

Table 3: Results from Real-time PCR

\begin{tabular}{ccc}
\hline Gene & \multicolumn{2}{c}{ Real-time PCR fold change } \\
\cline { 2 - 3 } & ACTB & 185 \\
\hline CYPI7AI & $2.28(p=0.0015)$ & $2.87(p=0.001)$ \\
CYB5 & $2.24(p=0.08)$ & $2.84(p=0.025)$ \\
FTL & $1.88(p=0.078)$ & $2.58(p=0.0026)$ \\
EEFIAI & $0.95(p=0.77)$ & $1.30(p=0.23)$ \\
\hline
\end{tabular}

Real-time PCR was used to confirm expression variations of selected genes from the microarray study. Normalisation of the values was performed by using ACTB and $18 \mathrm{~S}$ as control genes. Three of four examined genes were verified and one was contradicted. ble to use these genes as markers for low androstenone without simultaneously affecting levels of testosterone. However, further studies are needed to address this hypothesis.

In addition to FDX1, two additional ferritin cDNA clones were significantly up-regulated in the NLH and DH groups: FTL and the ferritin heavy-chain (FTH1). The differential expression of FTL was also confirmed by realtime PCR. Ferritin is an iron storage protein and plays a central role in numerous essential cellular functions [27]. Ferritin may also affect levels of androstenone through the CYB5/CYP450 electron transfer as the haem-containing cytochrome P450s need to receive electrons, e.g. from interaction with CYB5 [28], to be activated. 5-aminolevulinate synthase (ALAS1) is the first and rate-limiting enzyme in the haem biosynthesis pathway, providing haem for e.g. CYP450s [29]. This gene is up-regulated in $\mathrm{DH}$. The gene ontology results also suggest an important role for ferric iron/iron ion binding for the levels of androstenone in adipose tissue.

Cytochrome P450 c19 (CYP19) encodes the enzyme aromatase, which catalyses the synthesis of estrogens from androgens. The pig secretes unusually high levels of estrogens from the testes [30] and is the only mammal known 
Table 4: Results from the rcPCR bootstrap statistics (x4000), Duroc

\begin{tabular}{lccccc}
\hline Gene & Fold & Logl0 Fold change & Bias & Std error & P value \\
\hline SMPDI & 1.31 & 0.12 & 0.0008 & 0.09 & 0.097 \\
StAR & 5.4 & 0.73 & 0.0004 & 0.10 & 0.000 \\
SULT2AI & 2.3 & 0.37 & 0.0007 & 0.08 & 0.000 \\
HSDI7B4 & 1.7 & 0.24 & -0.0009 & 0.09 & 0.006 \\
AKRIC4 & 1.7 & 0.23 & 0.0013 & 0.09 & 0.003 \\
CYPIIAI & 2.4 & 0.38 & 0.0000 & 000 \\
\hline
\end{tabular}

rcPCR was used to confirm expression variations of selected genes from the microarray study. Fold changes are calculated relative to baseline, which is the group of low androstenone (DL) in this case, and adjusted for the housekeeping gene HPRT. Five of six examined genes were verified and one was contradicted.

to express functionally distinct isoforms of this gene [31]. Our results show an up-regulation of CYP19A2 isoform in both NLH and DH boars, whereas the CYP19A1 isoform was up-regulated in DH. Estrogens are shown to be positively correlated with androstenone levels in fat [32] and estrone sulfate levels in plasma have been found positively correlated with both plasma and fat levels of androstenone [33]. SMPD1 is involved in the conversion of sphingomyelin to ceramide, which has been shown to inhibit CYP19 activity through induction of transcription factors [34]. SMPD1 was down-regulated in DH animals in the microarray study, but we were not able to confirm this in the rCPCR analyses.

HSD17B4 was found up-regulated for both DH and NLH, in both microarray and rCPCR analyses. The 17 $\beta$-HSDs catalyse the last step in the formation of androgens and estrogens, and the HSD17B4 inactivates hormones very efficiently [35]. This has been reported for the substrates $17 \beta$-estradiol and 5 -androstene-3 $\beta, 17 \beta$-diol [36] but the enzyme also accepts other substrates [37]. The enzymes have previously been assigned to porcine Leydig and Sertoli cells [38] and porcine tissues express HSD17B4 as a predominant dehydrogenase [39]. Progesterone, a metabolite of pregnenolone, has been shown to increase porcine

Table 5: Results from the rCPCR bootstrap statistics (x4000), Landrace

\begin{tabular}{lccccc}
\hline Gene & Fold & Logl0 Fold change & Bias & Std error & P value \\
\hline SMPDI & 1.4 & 0.16 & -1.60 & 0.18 & 0.185 \\
StAR & 12.8 & 1.11 & -2.65 & 0.13 & 0.000 \\
SULT2AI & 2.4 & 0.38 & -4.37 & 0.11 & 0.002 \\
HSDI7B4 & 1.7 & 0.23 & -2.13 & 0.09 & 0.006 \\
AKRIC4 & 2.5 & 0.39 & -2.07 & 0.09 & 0.000 \\
CYPIIAI & 3.2 & 0.50 & 5.84 & 0.12 & 0.000
\end{tabular}

rcPCR was used to confirm expression variations of selected genes from the microarray study. Fold changes are calculated relative to baseline, which is the group of low androstenone (NLL) in this case, and adjusted for the housekeeping gene HPRT. Five of six examined genes were verified and one was contradicted.
HSD17B4 activity [39] and the progesterone receptor membrane component 1 (PGRMC1) was over-expressed in DH. Another $17 \beta$-HSD, isoform 11, also called dehydrogenase/reductase family member 8 (DHRS8) was down-regulated in DH boars.

AKR1C4 belongs to the cytosolic aldo-keto reductases that act as $3 \alpha-/ 3 \beta-/ 17 \beta-/ 20 \alpha$-hydroxysteroid dehydrogenases (HSDs) in human $[40,41]$ and was highly up-regulated in DH and NLH pigs. This was also confirmed by rCPCR. Penning et al. [36] showed that all the isoforms AKR1C1AKR1C4 could interconvert active androgens and oestrogens with their associated inactive metabolites, which prevents an excess of circulating steroid hormones and makes the steroids into substrates for conjugation reactions [40].

Nuclear receptor subfamily 5, group A, member 1 (NR5A1), also called steroidogenic factor 1 (SF-1), was over-expressed in DH boars. This transcription factor is involved in the regulation of numerous genes, including StAR [42], CYP11A [43], CYP17 [44] and CYP19 [45]. Also, nuclear receptor co-activator 4 (NCOA4), an androgen receptor (AR) activator often referred to as ARA70, was up-regulated in the DH group. The nuclear receptor co-activator 2 (NCOA2), another AR activator, was significantly over-expressed in NLH. Other genes regulating transcription and translation that were differentially expressed in this study include class III POU transcription factor (POU3F2), microtubule-associated protein light chain 3 isoform A (MAP1LC3A) and EEF1A1 which were up-regulated in the DH and NLH groups, eukaryotic translation elongation factor 1 beta (EEF1B2) which was upregulated in DH boars, and nuclear receptor subfamily 3 , group $\mathrm{C}$, member 2 (NR3C2) which was down-regulated in $\mathrm{DH}$ pigs.

Conjugation reactions contribute to the levels and pattern of steroids present in the plasma circulation of the boar. The enzymes involved in conjugation reactions were first thought to strictly inactivate and eliminate the compounds by rendering them more water-soluble. However, 
the high levels of conjugated steroids that are present in the plasma of the boar may suggest that the biological role of these reactions is more complex [46,47]. A common family of conjugation enzymes is the sulfotransferases. SULT2A1, also called hydroxysteroid sulfotransferase (HST), was up-regulated in both DH and NLH boars in the microarray experiment and subsequently confirmed by rCPCR. SULT2A1 is a key sulfotransferase enzyme in terms of the 16-androstene steroids, and its activity in the testis is negatively correlated to androstenone concentrations in fat $[19,48]$. Sulfotransferase family 2 isoform B1 (SULT2B1) is also a HST enzyme, showing selectivity for the conjugation of 3 3 -hydroxysteroids [49]. The SULT2B1 was significantly up-regulated in NLH pigs. The overexpression of the sulfotransferase genes in this study does not correspond to the negative correlation to levels of androstenone previously reported for this enzyme family [48].

Another conjugation reaction is catalysed by the glutathione S-transferases (GSTs). They have been shown to bind hormones [50] and influence their transport, metabolism and action [51]. One isoform of these enzymes (GSTalpha) is shown to be active in the pig testis Leydig and Sertoli cells and positively regulated by both estradiol and testosterone [52]. Glutathione S-transferase omega (GSTO1) and glutathione S-transferase (MGST1) were over-expressed in DH. These enzymes have not previously been studied in connection with androstenone; however, no correlation was found between fat skatole levels and glutathione S-transferase activity [53].

D and NL show many similar molecular functions and biological processes in this study, although they also differ with respect to which genes are differentially expressed. [54]. This miscellany might be due to the generally higher androstenone levels observed in D compared to NL [8]. The variability in the potential for androstenone production or elimination may to some extent be explained by breed differences in age at sexual maturity [55]. Differences between D and NL have also been shown by differential expression of $3 \beta$-hydroxysteroid dehydrogenase and SULT2B1 proteins, both enzymes critical for steroid production [54]. The higher number of significant genes in D compared to NL may be explained by the more extreme androstenone values in this breed (See Additional file 9: Androstenone values), giving higher contrasts.

In addition to the genes listed, we also identified several highly differentially expressed cDNA clones with no homology to known human or mouse sequences. Further characterisation of these genes may uncover new and unexpected roles in association with androstenone. The over-expression of for example AKR1C4, SULT2A1 and
SULT2B1 in high androstenone animals does not explain a role for these genes as inactivation enzymes and the role of these genes needs to be further studied in relation to androstenone levels. Additional studies of all the genes are necessary to see if their proteins show the same differential expression. Furthermore, identification of single nucleotide polymorphisms (SNPs) in the genes or in association with the genes can be used for breeding purposes. The exact function of genes from interesting gene ontology pathways, like ferric iron binding, iron ion binding, electron transport activities and oxidoreductase activities, also needs to be clarified.

\section{Conclusion}

Our study detected differentially expressed genes that are previously found to affect androstenone levels in boars, as well as genes from pathways not formerly described in this aspect. We confirm the involvement of CYP17 and CYB5 and detect a number of other genes involved in the steroid hormone pathway that seem to be essential for androstenone levels. Besides SULT2A1 we identified other conjugation enzyme genes that might be important, including SULT2B1, AKR1C4, GSTO1, MGST1 and $H S D 17 B 4$. The genetic profiles identified should be further examined to clarify their potential as molecular markers for reduced boar taint.

\section{Methods \\ Animals}

D and NL boars from NORSVIN's three boar testing stations were included in this study. The D and NL boars were on average 143 and 156 days at $100 \mathrm{~kg}$ live weight, respectively, and were slaughtered on average 14 days later. Tissue samples from testicle were frozen in liquid $\mathrm{N}_{2}$ and stored at $-80^{\circ} \mathrm{C}$ until used for RNA isolation as described below. Fat samples were collected from the neck and stored at $-20^{\circ} \mathrm{C}$ until used for androstenone measurements. Androstenone levels in fat were analysed by a modified time-resolved fluoroimmunoassay [56] using antiserum produced at the Norwegian School of Veterinary Science (NVH) [57]. A total of 1533 NL boars and 1027 D boars were analysed and statistical power calculations showed that selecting animals from each tail of the androstenone distribution was an effective way of obtaining high probability of finding differentially expressed genes with limited number of arrays. The power calculations suggested 30 arrays to be sufficient. Hence, for each breed, the 30 most extreme boars from each tail of the distribution were selected from all of the phenotyped animals (See Additional file 9: Androstenone values). In order to reduce family effects a maximum of two and three half sibs were chosen from NL and D, respectively. The same animals were used for verification of selected genes by rcPCR. Only D pigs were included in the real time PCR analysis. 


\section{Expression profiling using microarrays}

The microarrays (UltraGAPS coated slides, Corning Incorporated, MA, USA) were produced at the Faculty of Agricultural Sciences, Aarhus University and contained 27,774 cDNA clones printed in duplicates [58]. Out of these, 26,877 were PCR products amplified from cDNA clones and 867 were control DNA fragments. Of the 26.877 cDNAs, 21.417 map to 15.831 human gene transcript IDs corresponding to roughly $1.35 \mathrm{cDNAs}$ per gene transcript. The remaining $5.460 \mathrm{cDNAs}$ were thus estimated to cover around 4.036 gene transcripts yielding 19.867 gene transcripts in total. The annotation was done using NCBI Reference Sequence (RefSeq) database Release 11. The cDNA clones originated from the Sino-Danish sequencing project, covering $0.66 \times$ of the pig genome [59]. A more detailed description of the microarray can be found at the NCBI Gene Expression Omnibus (GEO [60]) database using the platform accession number GPL3608.

Total RNA for microarray studies and real-time PCR were extracted from testicle tissue using the RNeasy midi kit according to the manufacturer's instruction (Qiagen, CA, USA). Quantities were measured using a NanoDrop ND1000 Spectrophotometer (NanoDrop Technologies, DE, USA) and qualities were examined by the 28S:18S rRNA ratio using the RNA 6000 Nano LabChip ${ }^{\circledR}$ Kit on 2100 Bioanalyzer (Agilent Technologies, CA, USA). AminoallylcDNA was synthesised from $20 \mu \mathrm{g}$ of total RNA using the SuperScript indirect cDNA labelling system (Invitrogen Corporation, CA, USA) and labelled using ARES Alexa Fluor 488 or 594 labelling kit (Molecular Probes, OR, USA). Half of the samples were labelled with one dye and the other half with the other dye facilitating a direct balanced block hybridisation design, where the dye swap is balanced between the samples. As the animals are selected from a very large number of boars and the contrast between the two groups is extremely large, animals within each of the experimental group were treated as equal. We have prioritised a larger number of animals instead of hybridising all animals twice (with a dye swap), as we expect the biological variation to be greater than the technical variation. It may be noted that our experimental design eliminates the dye bias in the contrast 'high' versus 'low' androstenone, since SUM('high expressions')/30 minus SUM('low expressions')/30 is $\left(30^{*} \mathrm{H}+15^{*} \mathrm{R}+\right.$ $\left.15^{*} \mathrm{G}\right) / 30-\left(30^{*} \mathrm{H}+15^{*} \mathrm{R}+15^{*} \mathrm{G}\right) / 30=\mathrm{H}-\mathrm{L}$, where $\mathrm{H}$ (L) denotes effect of high (low) androstenone, R (G) denotes the effect of red (green) dye and 30 is the number of arrays. Spike-in RNA from the Lucidea Universal ScoreCard (Amersham Biosciences) was added to the cDNA reactions. "Green" spike-in RNA was added to the samples labelled with Alexa-594 and "red" spike-in RNA was added to the samples labelled with Alexa-488. Purification of the amino-modified and fluorescently labelled cDNA was done using the NucleoSpin 96 Extract II PCR
Clean-up kit (Macherey-Nagel, Düren, Germany), and a hybridization blocker (Invitrogen Corporation, CA, USA) containing polydA (Invitrogen Corporation, CA, USA) and Yeast tRNA (Invitrogen Corporation, CA, USA) was added. Each microarray was hybridised with one high and one low androstenone sample from the same breed, giving a total of 30 arrays for each breed. The high and low samples were paired randomly within each breed. Hybridisation was conducted in a Discovery XT hybridisation station (Ventana Discovery Systems, AZ, USA), followed by a manual wash and drying by centrifugation. More detailed descriptions of the microarray experiments are available at the GEO database through the series accession number GSE 7409.

The microarrays were scanned using a ScanArray Express scanner (Perkin Elmer Inc., MA, USA). Signal intensities were quantified using the ScanArray Express software and further analysis carried out in R version 2.2.1 [61] software package Linear Models for Microarray Analysis (Limma version 2.7.2) [62-64]. Mean foreground intensities were background corrected using the Edwards method [65] implemented in Limma using the median background intensities, and log-ratios were printtip loess normalised within arrays. The duplicate correlation function in Limma was used to consider the duplicate printing of each feature. As a quality check, MA-plots $\left(M=\log _{2} 594 /\right.$ $\left.\log _{2} 488, A=\left(\log _{2} 594+\log _{2} 488\right) / 2\right)$, image plots and box plots were constructed using the Limma tools for visualisation of the data before and after normalisation. For assessing differential expression, Limma uses linear models in combination with an empirical Bayes method to moderate the standard errors of the estimated log-fold changes. The nominal p-values were corrected for multiple testing by false discovery rates (FDR) using Benjamini and Hochberg approach [66] and adjusted p-values $<0.01$ were considered significant.

Since the Limma statistic provides a parametric test, it might be affected by outlier records. Therefore, we also conducted a more robust, but less powerful non-parametric test, namely Fisher's Sign Test (FST) [67].

The features of the arrays were mapped to a LocusLink identifier and an annotation package was built using the Bioconductor package AnnBuilder (version 1.9.14). Tests for significantly overrepresentation of GO terms $(\mathrm{p}<0.01$ and more than 10 significant genes) were conducted using the GOHyperG function of the Bioconductor package GOstats (version 1.6.0) [68,69].

\section{Quantitative rcPCR analysis and quantitative real-time RT-PCR analyses}

A real competitive (rc) PCR gene expression analysis was used to verify some of the results from the microarray 
study. The method is build upon the MassARRAY methodology using the Quantitative Gene Expression (QGE) iPLEX system (Sequenom, CA, USA). Total RNA was isolated from testes by using the automatic DNA/RNA extractor (BioRobot M48 workstation; Qiagen; CA, USA) and first strand cDNA synthesis was conducted on $0.5 \mu \mathrm{g}$ total RNA using SuperScript ${ }^{\mathrm{TM}}$-II Rnase $\mathrm{H}^{-}$Reverse Transcriptase (Invitrogen, Carlsbad, CA, USA). Purified total RNA was treated with TURBO DNA-free ${ }^{\mathrm{TM}}$ (Ambion, Huntingdon, UK) for removal of contaminating DNA. Assay designs for the genes included in this study (See Additional file 10: Gene transcripts included in the rCPCR analyses) were multiplexed into a single reaction using MassARRAY QGE Assay Design software (Sequenom, CA, USA). The competitors, a synthetic DNA molecule that matched the sequence of the targeted cDNA region at all positions except for one single base served as an internal standard for each transcript. A 10 -fold dilution of competitor was initially used over a wide range of concentrations to determine an approximate equivalence point, followed by a 7 fold dilution of competitor from $4.04 \times 10^{-11}$ to $1.43 \times 10^{-}$ 19 to achieve more accurate results. The cDNA and competitor were co-amplified in the same PCR reaction with the conditions $95^{\circ} \mathrm{C}$ for 15 minutes, 45 cycles each of $95^{\circ} \mathrm{C}$ for 20 second, $56^{\circ} \mathrm{C}$ for 30 seconds and $72^{\circ} \mathrm{C}$ for 1 minute, and finally $72^{\circ} \mathrm{C}$ for 3 minutes. After a clean-up step to remove unincorporated nucleotides, the PCR products served as templates for the primer extension reaction. The iPLEX reaction cocktail mix and PCR conditions were done as described in the Sequenom application guide [70]. Parallel PCR-reactions were performed for all samples and each of the products was printed with 2 replicates on a SpectroCHIP. The primer extension reaction generates distinct mass signals for competitor and cDNAderived products, and mass spectrometric analysis generated signals from which the peak areas were calculated.

Because of collaborative reasons between two labs, another verification method used for the $\mathrm{D}$ boars was quantitative real-time PCR. Gene specific primers for four selected genes were generated from the Primer 3 software (See Additional file 11: Real-time PCR primers). Porcine $A C T B$ and $18 \mathrm{~S}$ rRNA amplifier set probes were used as endogenous control for normalisation. The gene ACTB was detected by Taqman probe whereas other genes were detected by SYBR Green probes. The same Duroc RNA samples as the ones used for the microarray experiments were applied. The RNA was synthesised into first-strand cDNA using SuperScript II Reverse Transcriptase (Invitrogen Corporation, CA, USA). The real-time PCR reaction was composed of $5 \mu \mathrm{L}$ of Taqman master mix, $2 \mu \mathrm{L}$ cDNA, $0.3 \mu \mathrm{L}$ of forward and reverse primers $(10 \mu \mathrm{M})$ and 0.05 $\mu \mathrm{L}$ of probe $(10 \mu \mathrm{M})$. The real-time cycler conditions were $50^{\circ} \mathrm{C}$ for 2 minutes, $95^{\circ} \mathrm{C}$ for 10 minutes and 40 cycles each of $95^{\circ} \mathrm{C}$ for 15 seconds and annealing/extension at $60^{\circ} \mathrm{C}$ for 1 minute. Each reaction was conducted in triplicate on each individual sample with ACTB and 18S rRNA amplified as internal control genes. The real-time PCR amplification was performed using ABI PRISM 7900 HT sequence detection system. A cycle threshold value $\left(\mathrm{C}_{\mathrm{T}}\right)$ was recorded for each sample and a standard curve made from $4 \times, 2 \times, 1 \times, 0.5 \times, 0.125 \times$ and $0.0625 \times$ was used to calculate the relative mRNA levels.

In the rCPCR study, the gene expression levels of $\mathrm{H}$ and $\mathrm{L}$ androstenone boars were analysed using the software TITAN version $1.0-13$ [71] that runs in the $\mathrm{R}$ statistical environment. The raw data from the Genotype Analyzer Software (Sequenom) was imported into TITAN and analysed using the default values of linear least squares polynomial regression with 4000 bootstrap replicates. The cDNA concentrations were corrected with respect to the housekeeping gene (HPRT), and p-values and confidence intervals for the fold changes were calculated. Details about the TITAN software are available at web [72].

Quantification of the real-time PCR amplification was performed using ABI PRISM 7900 HT sequence detection system. The standard curve method was used to calculate the relative mRNA levels.

\section{List of abbreviations}

DH, Duroc High androstenone, NLH, Norwegian Landrace High androstenone, DL, Duroc Low androstenone, NLL, Norwegian Landrace Low androstenone, ACTB, $\beta$ actin, AKR1C1, Aldo-keto reductase family 1, member C1, AKR1C4, Aldo-keto reductase family 1, member C4, ALAS1, 5-aminolevulinate synthase, AR, androgen receptor, ARA70, androgen receptor, CYB5, Cytochrome b5, CYP11A1, Cytochrome P450, subfamily XIA, polypeptide 1, CYP17, Cytochrome P450 c17, CYP19, Cytochrome P450 c19, CYP51, Cytochrome P450 51, DHRS8, Dehydrogenase/reductase family member 8 , DMAPP, Dimethylallyl diphosphate, EBP, Emopamit-binding protein, EEF1A1, Translation elongation factor 1 alpha 1, EEF1B2, Translation elongation factor 1 beta 2, FDX1, Ferredoxin, FTH1, Ferritin heavy-chain, FTL, Ferritin light polypeptide, FST, Fisher's sign test, GO, Gene ontology, GSTO1, Glutathione S-transferase omega, HPRT, Hypoxanthine guanine phosphoribosyltransferase 1, HSDs, Hydroxysteroid dehydrogenases, HSD17B4, 17-beta-Hydroxysteroid dehydrogenase IV, HST, Hydroxysteroid sulfotransferase, IDI1, Isopentenyl-diphosphate delta isomerase, IPP, Isopentenyl diphosphate, limma, linear models for microarray analysis, MAP1LC3A, Microtubuleassociated protein light chain 3 isoform A, MGST1, Glutathione S-transferase, NCOA2, Nuclear receptor co-activator 2, NCOA4, Nuclear receptor co-activator 4, NR3C2, nuclear receptor subfamily 3 , group C, member 2, NR5A1, Nuclear receptor subfamily 5 group A member 1 , 
PGRMC1, Progesterone receptor membrane component 1, POU3F2, Class III POU transcription factor, rcPCR, real competitive PCR, SC4MOL, Sterol-C4-methyl oxidase isoform 1, SF-1, Steroidogenic factor 1, SMPD1, Sphingomyrlin phosphodiesterase 1, SNPs, single nucleotide polymorphisms, StAR, Steroidogenic acute regulatory protein, SULT, Sulfotransferase, SULT2A1, Sulfotransferase family 2A, dehydroepiandrosterone-preferring, member 1, SULT2B1, Sulfotransferase family 2A, dehydroepiandrosterone-preffering member 1

\section{Authors' contributions}

MM carried out microarray molecular work, performed statistical analysis and drafted the paper. TM was involved in power calculations, performing statistical analysis and contributed to the paper. SL was involved in planning the project and writing the paper. $\mathrm{CB}$ was involved in planning the project and in charge of the lab facilities performing the microarray studies. XW carried out the real-time PCR work. LNC was involved in the microarray molecular work. IB was involved in statistical analysis. EG coordinated the study, was involved in planning the project, carried out rcPCR molecular work, and contributed to writing the paper. All authors have read and approved the final manuscript.

\section{Additional material}

\section{Additional file 1}

Boxplot of the arrays. Boxplots displaying the average $\log _{2}$-ratio distribution of raw background corrected log ratios and printtiploess normalised $\log$ ratios for the Duroc ( $a$ and $c$, respectively) and Norwegian Landrace ( $b$ and $d$, respectively) arrays. After within array normalisation, the log ratios were evenly distributed around 0 , indicating no need for between array normalisation.

Click here for file

[http://www.biomedcentral.com/content/supplementary/1471-

2164-8-405-S1.png]

\section{Additional file 2}

Microarray results analysed using Limma, Duroc. Gene profiling was done using 30 arrays and the cut-off for differentially expressed genes was a p-value of 0.01 after FDR correction. A positive t-statistics indicates upregulation in animals with high androstenone values and vice versa. Mvalues are fold changes. The clone names are sequences with a hit to human, mouse or pig genes. Some genes are represented by several different clones on the array and may therefore show up more than once in the table, while some have no hits to the abovementioned species.

Click here for file

[http://www.biomedcentral.com/content/supplementary/14712164-8-405-S2.txt]

\section{Additional file 3}

Microarray results analysed using Limma, Norwegian Landrace. Gene profiling was done using 30 arrays and the cut-off for differentially expressed genes was a p-value of 0.01 after FDR correction. A positive tstatistics indicates up-regulation in animals with high androstenone values and vice versa. M-values are fold changes. The clone names are sequences with a hit to human, mouse or pig genes. Some genes are represented by several different clones on the array and may therefore show up more than once in the table, while some have no hits to the abovementioned species.

Click here for file

[http://www.biomedcentral.com/content/supplementary/14712164-8-405-S3.txt]

\section{Additional file 4}

Genes common for Duroc and Norwegian Landrace at $p<0.01$. There were 72 genes in common for Duroc and Landrace at significance level $p$ $<0.01$.

Click here for file

[http://www.biomedcentral.com/content/supplementary/14712164-8-405-S4.xls]

\section{Additional file 5}

Microarray results analysed using Fisher's sign test, Duroc. Gene profiling was done using 30 arrays and the cut-off for differentially expressed genes was a FDR of 0.01. A -1 indicates up-regulation, while a 1 indicates down-regulation in boars with high androstenone levels. The clone names are sequences with a hit to human, mouse or pig genes. Some genes are represented by several different clones on the array and may therefore show up more than once in the table, while some have no hits to the abovementioned species.

Click here for file

[http://www.biomedcentral.com/content/supplementary/14712164-8-405-S5.txt]

\section{Additional file 6}

Microarray results analysed using Fisher's sign test, Norwegian Landrace. Gene profiling was done using 30 arrays and the cut-off for differentially expressed genes was a FDR of 0.05. A -1 indicates up-regulation, while a 1 indicates down-regulation in boars with high androstenone levels. The clone names are sequences with a hit to human, mouse or pig genes. Some genes are represented by several different clones on the array and may therefore show up more than once in the table, while some have no hits to the abovementioned species.

Click here for file

[http://www.biomedcentral.com/content/supplementary/14712164-8-405-S6.txt]

\section{Additional file 7}

Gene ontology (GO) results for the cellular component ontology, Duroc. The genes differentially expressed at $p<0.01$ in Duroc were analysed for over-represented GO terms in the cellular component ontology ( $p$ $<0.01$ ).

Click here for file

[http://www.biomedcentral.com/content/supplementary/14712164-8-405-S7.txt] 


\section{Additional file 8 \\ Gene ontology (GO) results for the cellular component ontology, Nor- wegian Landrace. The genes differentially expressed at $p<0.01$ in Duroc were analysed for over-represented GO terms in the cellular component ontology $(p<0.01)$. \\ Click here for file \\ [http://www.biomedcentral.com/content/supplementary/1471- 2164-8-405-S8.txt] \\ Additional file 9 \\ Androstenone values. Animals were paired randomly between the high and low androstenone groups within each breed. The androstenone values $(\mu \mathrm{g} / \mathrm{g})$ in Duroc high $(\mathrm{DH})$, Duroc low $(\mathrm{DL})$, Norwegian Landrace high $(\mathrm{NLH})$ and Norwegian Landrace low (NLL) animals are shown. Click here for file \\ [http://www.biomedcentral.com/content/supplementary/1471- 2164-8-405-S9.doc] \\ Additional file 10 \\ Gene transcripts included in the rcPCR analyses. \\ Click here for file \\ [http://www.biomedcentral.com/content/supplementary/1471- 2164-8-405-S10.doc] \\ Additional file 11 \\ Real-time PCR primers. Primers designed to test four selected genes using quantitative real-time $R T-P C R$. \\ Click here for file \\ [http://www.biomedcentral.com/content/supplementary/1471- \\ 2164-8-405-S11.doc]}

\section{Acknowledgements}

The microarrays were constructed at the Faculty of Agricultural Sciences (DJF), University of Aarhus, and the work was financed by the Norwegian pig breeders association (NORSVIN) and The Research Council of Norway. Work at DJF was supported by the EU-project SABRE. We want to thank Elin Bergseth at NORSVIN for collecting samples, Dr. Peter Sørensen, Dr. Jakob Hedegaard, Henrik Hornshøj and Helle Jensen at the microarray platform at Aarhus University for kind assistance, Dr. Paul Oeth at Sequenom for performing the rcPCR primer design and Dr. RebeccaAyme Cue for valuable help with English grammar.

\section{References}

I. Babol J, Squires EJ, Lundström K: Relationship between oxidation and conjugation metabolism of skatole in pig liver and concentrations of skatole in fat. Journal of Animal Science 1998, 76:829-838.

2. Dijksterhuis GB, Engel B, Walstra P, Font i Furnols M, Agerhem H, Fischer K, Oliver MA, Claudi-Magnussen $C$, Siret $F$, Bèague MP, Homer DB, Bonneau M: An international study on the importance of androstenone and skatole for boar taint: II. Sensory evaluation by trained panels in seven European countries. Meat Science 2000, 54:261-269.

3. Vold E: Fleischproduktionseigenschaften bei ebern und kastraten. Meldinger fra Norges Landbrukshogskole 1970, 49:1-25.

4. Patterson RLS: 5alpha-androst-16-ene-3-one: - Compound responsible for taint in boar fat. Journal of the Science of Food and Agriculture 1968, 19:

5. Sellier P, Le Roy P, Fouilloux MN, Gruand J, Bonneau M: Responses to restricted index selection and genetic parameters for fat androstenone level and sexual maturity status of young boars. Livestock Production Science 2000, 63:265-274.
6. Varona L, Vidal O, Quintanilla R, Gil.M., Sànches A, Folch JM, Hortos M, Ruis MA, Amills M, Noguera.J.L.: Bayesian analysis of quantitative trait loci for boar taint in a landrace outbred population. Journal of animal science 2005, 83:30I-307.

7. Willeke $\mathrm{H}$ : Possibilities of breeding for low $\mathbf{5 a}$-androstenone content in pigs. Pig News and Information 1993, I 4:3IN-3.

8. Prevention of boar taint in pig production. Abstracts of the 19th Symposium of the Nordic Committee for Veterinary Scientific Cooperation, Gardermoen, Norway, 21-22 November 2005. Acta Vet Scand 2005, 48 Suppl I:PI-SI6.

9. Perry GC, Patterson RLS, MacFie HJH, Stinson CG: Pig courtship behaviour: pheromonal property of androstene steroids in male submaxillary secretion. Animal production 1980, 31:191-199.

10. Reed HCB, Melrose DR, Patterson RLS: Androgen steroids as an aid to the detection of oestrus in pig artificial insemination. British Veterinary Journal 1974, 130:6I-67.

II. Brooks RI, Pearson AM: Steroid hormone pathways in the pig, with special emphasis on boar odor: a review. Journal of animal science 1986, 62:632-645.

12. Katkov T, Gower DB: The biosynthesis of androst-16-enes in boar testis tissue. Biochemical journal 1970, I 1 7:533-538.

13. Meadus W], Mason Il, Squires El: Cytochrome P450 17 from porcine and bovine adrenal catalyses the formation of 5,16 androstadien-3 beta-ol from pregnenolone in the presence of cytochrome b5. Journal Steroid Biochem Mol Biol 1993, 46(5):565-572.

14. Davis SM, Squires E): Association of cytochrome b5 with 16androstene steroid synthesis in the testis and accumulation in the fat of male pigs. Journal of animal science 1999, 77:1230-1235.

15. Lin Z, Lou Y, Squires EJ: Identification of a single nucleotide polymorphism in porcine testis cytochrome P450-cl7 (CYPI7) and its effect on steroidogenesis. Biochemical genetics 2005, 43:53I-542.

16. Lin Z, Lou Y, Peacock J, Squires EJ: A novel polymorphism in the 5 ' untranslated region of the porcine cytochrome b5 (CYB5) gene is associated with decreased fat androstenone level. Mammalian genome 2005, 16:367-373.

17. Glatt H, Meinl W: Pharmacogenetics of soluble sulfotransferases (SULTs). Naunyn-Schmiedeberg's Archives of Pharmacology 2004, 369:55-68.

18. Sinclair PA, Squires EJ, Raeside JI, Renaud R: Synthesis of free and sulphoconjugated I6-androstene steroids by the Leydig cells of the mature domestic boar. I Steroid Biochem Mol Biol 2005, 96(2):217-228.

19. Sinclair PA, Squires EJ: Testicular sulfoconjugation of the 16androstene steroids by hydroxysteroid sulfotransferase: its effect on the concentration of 5alpha-androstenone in plasma and fat of the mature domestic boar. Journal of animal science 2005, 83:358-365.

20. Xue J, Dial GD, Holton EE, Vickers Z, Squires EJ, Lou Y, Godbout D, Morel $\mathrm{N}$ : Breed differences in boar taint: relationship between tissue levels of boar taint compounds and sensory analysis of taint. Journal of animal science 1996, 74:2170-2177.

21. Christenson LK, Strauss JF 3rd: Steroidogenic acute regulatory protein (StAR) and the intramitochondrial translocation of cholesterol. Biochim Biophys Acta 2000, I 529(I-3): 175-I87.

22. Grinberg AV, Hannemann F, Schiffler B, Müller J, Heinemann U, Bernhardt R: Adrenodoxin: Structure, stability, and electron transfer properties. Proteins 2000, 40(4):590-6/2.

23. Schiffler B, Zöllner A, Bernhardt R: Stripping down the mitochondrial cholesterol hydroxylase system, a kinetics study. The Journal of Biological Chemistry 2004, 279:34269-34276.

24. Debeljak N, Fink M, Rozman D: Many facets of mammalian lanosterol I 4alpha-demethylase from the evolutionarily conserved cytochrome P450 family CYP5I. Arch Biochem Biophys 2003, 409(I):|59-|7|

25. Silve S, Dupuy PH, Labit-Lebouteiller C, Kaghad M, Chalon P, Rahier A, Taton M, Lupker J, Shire D, Loison G: Emopamil-binding protein, a mammalian protein that binds a series of structurally diverse neuroprotective agents, exhibits delta8-delta7 sterol isomerase activity in yeast. The Journal of Biological Chemistry 1996, 27 I:22434-22440. 
26. Miller WL, Gaylor JL: Investigation of the component reactions of oxidative sterol demethylation. The Journal of Biological Chem istry 1970, 245:5369-5374.

27. Hentze MW, Kühn LC: Molecular control of vertebrate iron metabolism: mRNA-based regulatory circuits operated by iron, nitric oxide, and oxidative stress. Proc Natl Acad Sci U S A I996, 93( I 6):8|75-8|82.

28. Bonfils C, Balny C, Maurel P: Direct evidence for electron transfer from ferrous cytochrome b5 to the oxyferrous intermediate of liver microsomal cytochrome P-450 LM2. Journal of biological chemistry 1981, 256:9457-9465.

29. Fraser DJ, Zumsteg A, Meyer UA: Nuclear receptors constitutive androstane receptor and pregnane $X$ receptor activate a drug-responsive enhancer of the murine 5 -aminolevulinic acid synthase gene. The Journal of Biological Chemistry 2003. 278:39392-3940I.

30. Claus R, Hoffman B: Oestrogens, compared to other steroids of testicular origin, in bloodplasma of boars. Acta Endocrinologica |980, 94:404-4| I.

31. Corbin CJ, Khalil MW, Conley AJ: Functional ovarian and placental isoforms of porcine aromatase. Mol Cell Endocrinol 1995, I I3(I):29-37

32. Squires EJ, Gullett EA, Fisher KRS, Partlow GD: Comparison of androst-I6-ene steroid levels determined by a colorimetric assay with boar taint estimated by a trained sensory panel. Journal of animal science 1991, 69:1092-1 I00.

33. Babol J, Squires EJ, Lundstrom K: Relationship between metabolism of androstenone and skatole in intact male pigs. I Anim Sci 1999, 77:84-92.

34. Santana P, Llanes L, Hernandez I, Gallardo G, Quintana J, Gonzales J, Estevez F, Ruiz de Galarreta C, Fanjul LF: Ceramide mediates tumor necrosis factor effects on P450-aromatase activity in cultured granulosa cells. Endocrinology 1995, I 36:2345-2348.

35. Adamski J, Normand T, Leenders F, Monte D, Begue A, Stehelin D, Jungblut PW, de Launoit Y: Molecular cloning of a novel videly expressed human 80 kDa I7b-hydroxysteroid dehydrogenase IV. Biochemical journal 1995, 3 I I :437-443.

36. Adamski J, Husen B, Marks F, Jungblut PW: Purification and properties of oestradiol I $7 \mathrm{~b}$-dehydrogenase extracted from cytoplasmic vesicles of porcine endometrial cells. Biochemical journal I992, 288:375-38I.

37. de Launoit $Y$, Adamski J: Unique multifunctional HSD I $7 B 4$ gene product: I 7 b-hydroxysteroid dehydrogenase 4 and D-3 hydroxyacyl-coenzyme A dehydrogenase/hydratase involved in Zellweger syndrome. Journal of Molecular Endocrinology 1999, 22:227-240.

38. Carstensen JF, Tesdorpf JG, Kaufmann M, Markus MM, Husen B, Leenders F, Jakob F, de Launoit $Y$, Adamski J: Characterization of I 7 beta-hydroxysteroid dehydrogenase IV. Journal of endocrinology 1996, I50:

39. Kaufmann M, Carstensen J, Husen B, Adamski J: The tissue distribution of porcine $I 7 \mathrm{~b}$-estradiol dehydrogenase and its induction by progesterone. I Steroid Biochem Mol Biol 1995, 55(56):535-539.

40. Penning TM, Burczynski ME, Jez JM, Hung C, Lin H, Ma H, Moore M, Palackal N, Ratnam K: Human 3alpha-hydroxysteroid dehydrogenase isoforms (AKRICI-AKRIC4) of the aldo-keto reductase superfamily: functional plasticity and tissue distribution reveals roles in the inactivation and formation of male and female sex hormones. Biochemical journal 2000, 35 I:67-77.

4I. Steckelbroeck S, Jin Y, Gopishetty S, Oyesanmi B, Penning TM: Human cytosolic 3alpha-hydroxysteroid dehydrogenases of the aldo-keto reductase superfamily display significant 3 beta-hydroxysteroid dehydrogenase activity. Implications for steroid hormone metabolism and action. Journal of biological chemistry 2004, 279: I 0784- 10795

42. Sugawara T, Kiriakidu M, McAllister JM, Kallen CB, Strauss III JF: Multiple steroidogenic factor I binding elements in the human steroidogenic acute regulatory protein gene 5'-flanking region are required for maximal promoter activity and cyclic AMP responsiveness. Biochemistry 1997, 36:7249-7255.

43. Clemens JW, Lala DS, Parker KL, Richards JS: Steroidogenic factor-I binding and transcriptional activity of the cholesterol side-chain cleavage promoter in rat granulosa cells. Endocrinology 1994, I34:|1499-1508.
44. Bakke $M$, Lund J: Mutually exclusive interactions of two nuclear orphan receptors determine activity of a cyclic adenosine 3',5'-monophosphate-responsive sequence in the bovine CYPI 7 gene. Molecular endocrinology 1995, 9:327-339.

45. Fitzpatrick SL, Richards JS: Cis-acting elements of the rat aromatase promoter required for cyclic adenosine 3',5'-monophosphate induction in ovarian granulosa cells and constitutive expression in R2C Leydig cells. Molecular endocrinology 1993, 7:34I-354

46. Coughtrie MWH, Sharp S, Maxwell K, Innes NP: Biology and function of the reversible sulfation pathway catalysed by human sulfotransferases and sulfatases. Chemico-biological interactions 1998, 109:3-27.

47. Sinclair PA, Squires EJ, Raeside Jl, Renaud R: Synthesis of free and sulphoconjugated I6-androstene steroids by the Leydig cells of the mature domestic boar. J Steroid Biochem Mol Biol 2005, 96(2):217-228.

48. Sinclair PA, Gilmore WJ, Lin Z, Lou Y, Squires EJ: Molecular cloning and regulation of porcine SULT2AI: relationship between SULT2AI expression and sulfoconjugation of androstenone. Journal of Molecular Endocrinology 2006, 36:30 I-3 I I.

49. Meloche CA, Falany CN: Expression and characterization of the human 3 beta-hydroxysteroid sulfotransferases (SULT2B I a and SULT2B I b). J Steroid Biochem Mol Biol 200 I, 77(4-5):26 I-269.

50. Listowsky I, Abramovitz M, Homma H, Niitsu Y: Intracellular binding and transport of hormones and xenobiotics by glutathione S-transferase. Drug metabolism reviews 1988, 19:305-318.

51. Homma H, Listowsky I: Identification of Yb-glutathione-Stransferase as a major rat liver protein labeled with dexamethasone 2 I-methanesulfonate. Proc Natl Acad Sci U S A 1985 , 82(2I):7165-7|69.

52. Benbrahim-Tallaa L, Tabone E, Tosser-Klopp G, Hatey F, Benahmed $M$ : Glutathione S-transferase alpha expressed in porcine sertoli cells is under the control of follicle-stimulating hormone and testosterone. Biology of reproduction 2002, 66: I734- 1742

53. Diaz GJ, Squires EJ: Phase II in vitro metabolism of 3-methylindole metabolites in porcine liver. Xenobiotica 2003, 33:485-498.

54. Moe M, Grindflek E, Doran O: Expression of 3beta-hydroxysteroid dehydrogenase, cytochrome P450-cl7, and sulfotransferase 2B I proteins in liver and testis of pigs of two breeds: relationship with adipose tissue androstenone concentration. J Anim Sci 2007, 85( I I ):2924-293 I.

55. Christenson RK, Ford J]: Puberty and estrus in confinementreared gilts. Journal of animal science 1979, 49:743-75I.

56. Tuomola M, Harpio $R$, Knuuttila $P$, Mikola $H$, Løvgren $T$ : Timeresolved fluoroimmunoassay for the measurement of androstenone in porcine serum and fat samples. Journal of Agricultural Food Chemistry 1997, 45:3529-3534

57. Andresen $O$ : Development of a radioimmunoassay for $\mathbf{5}$ alpha-androst-16-en-3-one in pig peripheral plasma. Acta Endocrinol (Copenh) 1974, 76(2):377-387.

58. Gorodkin J, Cirera S, Hedegaard J, Gilchrist MJ, Panitz F, Jorgensen C, Scheibye-Knudsen K, Arvin T, Lumholdt S, Sawera M, Green T, Nielsen BJ, Havgaard JH, Rosenkilde C, Wang J, Li H, Li R, Liu B, Hu S, Dong W, Li W, Yu J, Wang J, Staefeldt HH, Wernersson R, Madsen LB, Thomsen B, Hornshoj H, Bujie Z, Wang X, Wang X, Bolund L, Brunak S, Yang $H$, Bendixen C, Fredholm M: Porcine transcriptome analysis based on 97 non-normalized cDNA libraries and assembly of $I, 02 I, 89 I$ expressed sequence tags. Genome Biol 2007, 8:R45.

59. Wernersson R, Schierup RH, Jørgensen FG, Gorodkin J, Panitz F, Staerfeldt $\mathrm{HH}$, Christensen OF, Mailund T, Hornshøj $\mathrm{H}$, Klein A, Wang J, Liu B, Hu S, Dong W, Li W, Wong GK, Yu J, Wang J, Bendixen C, Fredholm M, Brunak.S., Yang $H$, Bolund $L$ : Pigs in sequence space: a $0.66 \mathrm{X}$ pig genome survey based on shotgun sequencing. BMC Genomics 2005, 6:

60. 2007 [http://www.ncbi.nlm.nih.gov/geo/]

6I. Ihaka R, Gentleman R: R: A language for data analysis and graphics. Journal of Computational and Graphical Statistics 1996 , 5:299-3। 4.

62. Smyth GK: Linear models and empirical bayes methods for assessing differential expression in microarray experiments. Stat Appl Genet Mol Biol 2004, 3:Article3. Epub

63. Smyth GK, Speed TP: Normalization of cDNA microarray data. Methods 2003, 31:265-273. 
64. Smyth GK: Limma: linear models for microarray data. In Bioinformatics and Computational Biology Solutions using $R$ and Bioconductor Edited by: Gentleman R, Carey V, Dudoit S, Irizarry R and Huber W. New York, Springer; 2005:397-420.

65. Edwards D: Non-linear normalization and background correction in one-channel cDNA microarray studies. Bioinformatics 2003, 19(7):825-833.

66. Benjamini $Y$, Hochberg Y: Controlling the false discovery rate: $\mathbf{A}$ practical and powerful approach to multiple testing. Journal Of The Royal Statistical Society Series B 1995, 57:289-300.

67. Hollander M, Wolfe DA: Nonparametric statistical methods Wiley, New York; 1973.

68. Falcon S, Gentleman R: Using GOstats to test gene lists for GO term association. Bioinformatics 2006, 23:257-258.

69. Hedegaard J, Skovgaard K, Mortensen S, Sørensen P, Jensen TK, Hornshøj H, Bendixen C, Heegaard PM: Molecular characterisation of the early response in pigs to experimental infection with Actinobacillus pleuropneumoniae using cDNA microarrays. Acta Vet Scand 2007, 49(1): I I.

70. 2007 [http://www.sequenom.com].

7I. Elvidge GP, Price TS, Glenny L, Ragoussis J: Development and evaluation of real competitive PCR for high-throughput quantitative applications. Analytical Biochemistry 2005, 339:23I-24I.

72. 2007 [http://itmat.upenn.edu/ tsprice/software.html].

\section{Publish with Bio Med Central and every scientist can read your work free of charge}

"BioMed Central will be the most significant development for disseminating the results of biomedical research in our lifetime. "

Sir Paul Nurse, Cancer Research UK

Your research papers will be:

- available free of charge to the entire biomedical community

- peer reviewed and published immediately upon acceptance

- cited in PubMed and archived on PubMed Central

- yours - you keep the copyright

Submit your manuscript here:

http://www.biomedcentral.com/info/publishing_adv.asp
BioMedcentral 